\title{
The global trope and urban redevelopment: the American experience
}

\author{
D. Wilson \\ University of Illinois at Urbana-Champaign, Department of Geography, 607 South Matthews Avenue, Urbana, \\ Il 61801, USA \\ Correspondence to: D. Wilson (dwilson2@illinois.edu)
}

Received: 2 August 2012 - Revised: 6 March 2013 - Accepted: 24 March 2013 - Published: 22 July 2014

\begin{abstract}
This paper examines a new "political opportunity structure" in United States Rust Belt cities - globalization - currently being used by redevelopment governances. An investigation of two cities reveals that this discourse ("the global trope") has helped to produce a new socio-spatial polarization in US cities. Globalization here is now not merely a new reality, but also a powerful rhetorical device whose invoking is proving to be a potent political tool for capital in its drive to transform cities. At this rhetoric's core, a supposed new hyper-competitive reality makes Rust Belt cities easily discardable as places of investment. These once-enclosed containers of "the economic", in the rhetoric, have recently become leaky landscapes rife with a potential for economic hemorrhaging. Against this supposed reality, cities are portrayed as beset by a kind of accumulation disorder that now haunts them. Through this, the new governmentality's dominant contours - a proposed shock treatment of re-regulation - is rationalized. This generates a new uneven development across US cities that marginalizes low-income African-American communities.
\end{abstract}

\section{Introduction}

Academics across the global north now widely chronicle globalization as the dominant force that currently molds the economic fabric of and redevelopment agendas in cities. Globalization, it is documented, facilitates the rise of the "entrepreneurial city" with its "new urban politics", a relationship that powerfully directs these cities into the future (Kirkpatrick and Smith, 2011; Hackworth, 2012). Harvey (1989, 2012) echoes a dominant belief in noting that globalization shapes these terrains via an accelerated time-space compression that "hyper-mobilizes" businesses, industries, and speculative investors. To Harvey, cities across the global north now desperately respond to a new ferocious reality of capital dramatically freed up to produce and conduct transactions in a hyper-mobile world. The result, to Harvey (2012), is a globalization that now expands beyond "the economic" to penetrate other city, regional, and societal spheres: the cultural, the political, and the social.

Yet, with increased understanding of this process, some have begun to recognize that globalization's effects also extend to something else: institutions and governances using this reality as a central exaggerated and caricatured ingredient in discourse to propel political agendas (Wilson, 2007; MacLeod, 2011). This notion, labeled by analysts "the global trope" (Wilson, 2007), identifies globalization's effects as an expedient rhetorical invoking. The rhetoric of the global trope, identified as a perceptual apparatus with profound material effects, has been chronicled as serving up a digestible reality that informs the building of redevelopment programs (Rauch, 2013). As "discursive capital", it projects select redevelopment schemes as reasonable and rational and others as seemingly irrational. Interconnected entanglements of meanings, guiding, and ensnaring craft limits around comprehensions of the world that strives to locate visions within limited, constricted vistas. A tacit dialogue with diverse visions asserts one vision and annihilates others, offering a calculated affirmation and rebuke. This politicized accepting and rejecting, boldly asserting core redevelopment realities and truths, make this rhetorical formation a core apparatus of power.

This research deepens our understanding of this global trope. With the above outlined, we still know remarkably 
little about this process, even as we now recognize its existence and ever-evolving, fluid character set in contingent local settings (Machimura, 1998; Nash, 2010). Two important issues about this rhetorical constructing and usage remain most tantalizingly vague: its complex internal content and its impacts. Urban rhetorical formations in general, urbanists and social scientists realize, are nuanced human constructs that contain a rich mélange of devices to make them work, e.g., metaphors, similes, synecdoches, and alliterations (Lakoff and Johnson, 1985; Langellier, 2004; MacLeod and Jones, 2011). These devices, casts of characters, interconnected themes, and processes move through text that coalesces to produce offerings of coherent stories (Dalke and Grabstein, 2007; Wilson, 2007). Yet, such specifics, applied to the global trope, remain unclear. Moreover, the specificities of how this global trope precisely impacts the redevelopment process are undocumented. It is one thing to surmise about these effects; it is another to chronicle in detail their workings.

This study chronicles the internal content and impacts of the global trope in two US cities: Indianapolis (or Indy for short) and Cleveland. In both cities today, redevelopment governances (like many in the global north) aggressively strive to remake physical and social fabrics via invoking the realities of new global times. These cities, in place-specific redevelopment narratives, face a new grim reality - dark and deepening global times - which ominously hovers to batter and threaten their economic fortunes. The adroit scripts, deftly incorporating finely changing social values and new political wrinkles, convey bluntness and brutishness: a new hyper-mobility of capital "annihilative of space by time" looms to eradicate jobs, investment, and manufacturing. Today, the narratives communicate, there is a desperate city competition for new investment and businesses across the United States and the world. A handful of cities are in the process of boldly remaking themselves to be "global centers" (e.g., New York, Chicago), other cities (supposedly less advantaged) purportedly struggle to either sustain a "regionalcity" status, stabilize, or simply survive.

In this paper two cities - Indianapolis and Cleveland are chosen for investigation for an important reason: they are, in key ways, prototypes of the current deindustrializing global north city. Even as these cities (like all cities) exhibit key unique features and attributes that must be considered in their analysis, they also have widely shared economic histories with the likes of London, Glasgow, Newcastle, Leipzig, Birmingham, and Duisburg, i.e., they have been steeped in manufacturing and industrial production as classic northern "rusting cities" (Wilson, 2004; Porsky, 2012). As their economic foundations have eroded in recent decades, driven by the departures or closures of many industries, these cities have struggled to reinvent their economic missions. Postindustrialism has not come easy to either place, a reality that now grips many cities in the US, UK, Germany, Canada, and beyond. Both cities, moreover, have experienced what many cities in the global north today incorporate: the rise of neoliberal redevelopment governances. These governances, reflecting the tenor of new social and political times, aggressively strike out to redevelop via emphasizing the primacy of the private market, reduced government involvement, and the prowess of public-private partnerships (Porsky, 2012; Hackworth, 2012).

The methods for acquiring and interpreting data were straight-forward. Data was obtained via two techniques: open-ended discussions with interviewees and textual analysis of newspapers and city technical reports. Open-ended discussions were conducted in the two cities across an expansive time frame: in 1992, 1997, 2004, 2005, 2007, 2008, 2009, 2010, 2011, 2012, and 2013. Diverse actors - local planners, city officials, community activists, real-estate developers, realtors, residents - were interviewed in person or by telephone. Open-ended questions queried actor involvement in, perceptions of, and opinions about recent and ongoing redevelopment. Conversations were designed to be informal; terms and language used were guided by respondent's choice of words. All interviewees were initially asked if they preferred to have their names withheld from future writeups. Nearly $90 \%$ of the 50 interviewees opted for this. For this reason, comments by discussants were identified with pseudonyms.

Textual analysis, used to deepen insights about redevelopment and to cross-verify findings, deconstructed stories about city growth, city redevelopment, and city restructuring in two local dailies, the Indianapolis Star and Cleveland Plain Dealer. These papers were selected for review because of their immense local popularity (they have the widest circulation in their respective cities) and are important rhetorical outlets for the mainstream planning communities in both cities (Wilson, 2007). As in the open-ended discussions, articles were extracted across the same expansive time frame. I performed a literature search, using Lexus Nexus and the search words "development", "redevelopment", "city change", "Cleveland globalization", "Indianapolis globalization", and "ghetto" to obtain approximately 110 articles. Approximately 25 stories were also found and deconstructed from the web, using the same terms. Web usage enabled a further deepening of insights and an additional crossverification of findings that enhanced the veracity of the data interpretation.

\section{Content of the global trope}

I discovered, first, that the global trope in Indianapolis and Cleveland is an evolving, multitextured rhetorical formation that fervently pushes a "global redeveloping" and emphasizes two locations: their downtowns and nearby neighborhoods. A nonfixed rhetoric works through place-specific sensibilities to vehemently advance one redevelopment vision and geography while simultaneously purging alternatives. 
Here is Bakhtin's (1981) temporally and spatially specific "chronotope" which offers one vision and conducts an implicit dialogue with other points of view (Cameron and Palen's (2003) dialectic of embrace and spurn). Yet, in elaborate cover, the trope is continuously reduced to something else, what Indianapolis planner S. Hawes (2009) termed "simple and straight ahead truths about city conditions and circumstances ... that need to be stated widely".

At this rhetoric's center, a supposed new ultra-competitive reality makes these cities easily peripheralized as zones for investment, production, and business. This global-speak has the once confident and stable enclosures of the economic that have recently become hemorrhaging, porous terrains rife with a potential for a dramatic economic eclipse. Against this supposed reality, these cities are portrayed as uniquely beset by a kind of evolving accumulation disorder and uncertainty that now haunts them.

In ultra-conservative Indianapolis, the narrative is distinctive. Indianapolis, before 2007 , was purportedly plagued by an overextended welfare state that obstructed the private market and attempts to implement a global-fighting investment climate. Obtrusive government, in short, circumvented a progressive entrepreneurial response. After 2007, this theme subtly morphed to become more a dilemma rooted in a more ambitious and global-looking capital that lost much of its hesitancy to "globalize" and leave Indy. The narrative, lessening its pummeling of the local state, now centers a notion of globally rooted capital in the city for villainizing. Indianapolis city-county councilor G. Howard (2008) reflected this in noting these twin themes to me: "Indy's always been troubled by the drive to make an ideal place for investors to come and stay; we've worked unsuccessfully at that ... and now conditions have become worse ... we face these crazy business people who really desire [more than ever] to go elsewhere ... they're just crazy and selfish, man".

The theme in Cleveland, alternatively, has changed little: the public and private sectors have been unable to marshal the collective energy to contest the power of hyper-mobile capital and the allure of their departure. A vague, shadowy notion of a public retreat from confronting globalization has dominated here. The power and prowess of hyper-mobile capital, now, renders the drive to protect the city economic base ineffective. As Cleveland planner S. Plann (2004) commented, with "the rise of the global era this thing called globalization makes capital just incredibly mobile - more footloose than in the past ... it will go where it is wanted and stay where it is well treated ... that's our reality today, what we're up against". "Standing up to this new reality", to Plann, "will have to involve a lot more than what we are currently doing ... the public has to see this".

Yet, the rhetoric in both cities strategically includes a sense of hope for contesting globalization. In both cities, the narrative presents environments that are still proactive and capable of blunting globalization's influence. This inclusion of hope in the narratives, a deft offering, opens up the sense that rede- velopment initiatives can be potentially groundbreaking municipal action. In this context, this inclusion of hope has appeared relatively recently in the narratives; before 2006, any invoking of staunch combat and hope was submerged under renditions of globalization's raw power. Cleveland planner S. Plann (2004), recently reflecting this new addition in commentary, noted, "Face it: we [Cleveland] are threatened ... but are also a highly resilient city that, one more time, must be courageous and innovative to fight for what we have [jobs, companies]".

To drive this point home, the governances frequently narrate a private sector, public sector, and planners in both cities (narrated side by side with globalization) as poised and readied to wholeheartedly thwart globalization's influence. These potential city salvationists, the forwarded ray of hope on the horizon, vary slightly in the two cities. "What we need [to blunt globalization]", to Indy planner M. Rhoads (2011), "is a signal from the people and the policy community that a war needs to be waged ... led by planners and the business community, there would be no quit". Cleveland's redevelopment governance, working through a more Democratic city's greater faith in public sector initiatives, speaks of their public sector's "expertise and potential to meaningfully tackle globalization ... the assets and resources of local government that could make a difference" (city councilor R. Reeves, 2011).

The notion of city survival, this way, becomes an important analytic inclusion in the narrative. These cities, now, have to pursue two crucial imperatives to thwart city decline: strengthen the city as a taut entrepreneurial space and meticulously contain black ghettos and their populations. In the first imperative, the assertion is forceful: cities must push to build attractive consumptive complexes, upper-income residential spaces, efficient labor pools, and healthy business climates. This post-1990 rhetoric has been at the heart of what Cox (1993) identified as the supplanting of a "politics of redistribution" by a "politics of resource attraction". Entertainment, culture, sports, and leisure now become crucial civic business. To fail to commodify these, paraphrasing Indianapolis Mayor William Hudnut (1995), is to ignore the new steppedup competition for investment, jobs, and resources between cities. In the process, an intensified balkanizing of city space by class and race is not merely normalized; it becomes celebrated as utilitarian and put in the service of city survivability. Cleveland planner G. Marks (2008), reflecting this notion, noted that "the next great wave of city change ... we are now seeing this all across the urban United States because it's got to be done ... globalization is here - end of story".

In a second, darker imperative, black ghettos and their populations are referenced as in need of systematic isolating as damaged and civic-afflicting elements. Sanitized innuendo has them culturally problematic, counter "go-global" city spaces that need to be feared, disciplined, and cordoned off. Both Cleveland and Indianapolis have complex histories of problematic race relations (Warf and Holly, 1997; Wilson, 2007): this ethos in both cities has been systematically 
worked through. Thus, comments by Indy planner B. Braggs (2004) note the following: "Over the past 15 years community leaders have recognized that the city can no longer afford ghettos and their unproductive citizens. We [can't advance] in any meaningful way this is not the way a 21 st-century city functions in a global world". At work is the seamier side of Wimsett's (1998) notion of the mobilized fear economy, a general trepidation that now expands to more deeply include black ghettos in these two cities. A wave of fear, forwarded through elaborate images, illuminates black bodies and spaces as potential violators of the collectivity's sociomoral and economic integrity.

In offering this multiplicity of themes, the global trope narrates an elaborate cast characters and processes. Actors, institutions, and agents, made to move effortlessly through the narratives, provide it form, meaning, and substance. In both cities, the cornerstone of this is a central figure: an offered new footloose and place-detached business person that now dominates local economies. These business people, in theme, cannot be domesticated and tamed: any appearance of this is simply illusion. In these narrations, a kind of economic savagery compels them, saturating what Indianapolis Representative M. Henry (2008) terms "their illusive motives and actions". Now, in the narratives, the public has to be adroit and responsive, and think about something crucial: how this selfinterest can be manipulated to serve city interests. As Cleveland planner S. Swerve (2009) put it, "If it's economic climates and lax regulations that these business people so want, maybe this is what we [the city of Cleveland] should be providing".

At the same time, the global trope narratives offer another important figure: a new heroic, combative Rust Belt leader, writer Mosiman's (2002) "new entrepreneurial mayor". This inclusion is especially pronounced in Indianapolis, with its history of charismatic, pro-business mayors (e.g, William Hudnut, Stephen Goldsmith). In Cleveland, this figure is periodically referenced. Discussions about these mayors, a strategic politics, identify civic visionaries whose skills and insights make them logical people to spearhead the new needed restructuring: they are cast as emboldened and allseeing neoliberal beings, Bakhtin's (1981) "eye of reason". Through them, the public is to see something crucial: a rational, omniscient voice that clarifies municipal ills and best solutions. This voiced hero, made to revel in a kind of analytic virtuosity, ultimately collapses an inchoate process ("new global times") into easily understood images of a new civic problem, the solution, and the appropriate leaders to direct change. Thus, the Indianapolis Regional Center Plan (2001), a public-private city growth consortium, notes that "the new breed of big city mayors has welcomed business back into the city, stressed performance and results at city agencies, downplayed divisive racial politics, and cracked down on the symptoms of social disorder." "As a consequence", to the consortium, "America's cities [can] become vital communi- ties once again." There could be no better agent of change, the consortium notes, for these globally challenged cities.

But this mayoral construct also embodies sophistication at a deeper level. In particular, a hybrid personality is deftly sculpted to frame assertions of benevolent, pro-business, city-serving beings. In narrating them, then, these mayors are made to carry a privileged place of birth, ideal kinds of socialization and values, and important educational backgrounds to create a key signifier: a locally grounded, neoliberal being. Media narrations of one of the United States' post-1990 neoliberal political darlings, Mayor Stephen Goldsmith of Indianapolis, illustrate this. He has been widely depicted, first and foremost, as an attuned, intuitive neoliberalist who knows local life. Bearing the local in his soul, he strikes out to enhance what the sensible Indy community supposedly wants: a business-oriented and driven city rife with middle-class livability. To local planner B. Braggs (2004, 2013), "Indy claims Goldsmith as its own ... he was raised and educated here [and] grew to a man knowing what made Indy special and vibrant; he re-energized local spirits and the business community with projects ... that gave us pride and national standing" (see more of his measures in the case study further down).

In the subtleties of the rhetoric, moreover, these super mayors and media would be irresponsible if they did not identify a dilemma facing these cities: enigmatic black ghettos. The depictions take numerous forms. To Mayor Goldsmith (2003a), industrial cities like Indianapolis today find themselves in "[a] free fall [that] mayors found when they came to office during the 1990s." Mayors, to Goldsmith, are "fellow foot soldiers in a war that pits us openly against poverty and the force of urban decay also against our own state and federal governments." The problem is "counterproductive welfare programs, public housing initiatives, and a 'war on poverty', all of which simply exacerbate the plight." In Cleveland, influential but controversial city councilperson A. Moos (2008) got into the act, terming the city's biggest problem "a trap of global realities paralleled by neighborhoods and their people who refuse to be civic and help remake our city into something more productive and competitive on the global scene".

These invocations of black ghettos and their populations ultimately treat these in a curious way: compassion is allocated but to restless and counter-civic beings that seem more wild and wooly than deprived. Notions of context and struggle frequently punctuate presentations, but of a fantastically out-of-control people and places that seem to be working counter to city efforts at confronting globalization. Inner-city fears and fantasies of black neighborhoods and black ritualized life, this way, are adroitly mapped onto this global-city terrain. These spaces and populations, amid detail, remain abstract phenomena, what Kennedy (2000) calls a sociopsychological fantasy.

The global trope narratives in these two cities, ever evolving and working through place-specific sensibilities, 
ultimately project two important themes that normalize neoliberal redevelopment values and ideals. They offer, first, the "truths" of what circumstances these cities now face and, second, what these cities must do to survive. These are complementary themes that anchor a coherent rendition of now economically threatened cities whose obstacles to addressing globalization are visible and easily understood. In the following case studies, we will investigate how these two complementary themes become translated into city redevelopment in the two cities, respectively.

\section{The impacts}

The paragraphs that follow chronicle the major impact of the global trope in Cleveland and Indianapolis. I reveal this "discursive instrument" dramatically deepens a socio-spatially polarizing uneven development as urban redevelopment responds to an aggressive governance assertion of terrifying, eviscerating global possibilities. Three key processes are fueled by this rhetoric to have this effect: investment concentrating in gentrification enclaves and select downtown areas; an intensification of disciplining forms of state intervention that impose market rule across urban space; and policy that explicitly fragments these cities into mosaics of "deserving" and "undeserving" terrains.

\subsection{Cleveland}

In post-1990 Cleveland, the "global-touting" administrations of Michael White, Jane Campbell, and Frank Jackson have repetitiously presented Cleveland as a globally threatened place but also capable of progressive response. Reportage and oratory offer a city engulfed in new global times but historically resilient and capable of acting innovatively to survive. Most monumentally, the Civic Task Force on International Cleveland (2003), an influential group formed by the business community and local government to assess "the global-city question", calls the city a place with "an opportunity to revitalize[;] through continued internationalization of population and employment opportunities economic revitalization [can] occur." In meetings and engagements across Cleveland (business meetings, city council sessions, interviews with the media), their rhetoric has been constant: Cleveland is a fixed, immobile, and entrapped place that stares at something bewildering: new global times.

At the same time, they offer an easy-to-decipher oratory that centers a key obstacle to Cleveland becoming more globally competitive: the impacts of city noncontributory black ghettos. Here, in suggestion, is a non-civic space that will damage Cleveland's go-global redevelopment efforts. This space, in clear theme, is best marginalized amid new global realities. Thus, government involvement with the city's massive Eastside black ghetto, to popular mayoral candidate Triozzi (2005), should involve policing and managing this space while recognizing that it should not be a focus of redevelop- ment efforts. We should provide it [East Cleveland] with "police mini-stations but [first] put Cleveland back on the economic development map". Cuyahoga County commissioner Jimmy DiMora (2005) agrees: "Planning now [should] build on Cleveland's arts and cultural industry as if our community's future depend[ed] on it." To DiMora, Cleveland must "entrepreneurialize" its urban fabric to rebuild the city's cultural and business foundations that should dominate city redevelopment.

To put this into perspective, this new redevelopment template is not entirely new. Cleveland, long the quintessential blue-collar American city, had pre-1980 experienced a traumatic deindustrialization. This transformation was particularly pummeling between 1971 and 1981, with closure of some of its largest plants (US Steel, General Motors' Coit Road, Westinghouse, six General Electric plants) (Warf and Holly, 1997). To stem this tide, the growth governance in the mid-1980s toiled to craft gentrification in select downtown neighborhoods and the core. Cleveland's horrifically poor and predominantly black Eastside became forgotten and neglected by public policy (Margulis, 1998). Key foundational additions were the Rock and Roll Hall of Fame, the Old City and the Flats gentrification districts, Gund Arena, and new downtown hotels and clubs. Throughout, the governance "shot out" a steady supply of rhetorical support, and worked to symbolically bury the image of "the mistake by the lake" under the hype of the Chamber of Commerce's term "the comeback city".

Now, in the post-1990 new restructuring, the push has been to build on this foundation and etch into downtown a deeper privatopia of wealth and upper-income consumptive possibilities. This vision has involved something crucial: deepening a class-race-differentiated city via cultivating a mosaic of variegated districts and communities. At the core, centerpiece projects have been the full-fledged revitalizing of the Flats district, Old City, Public Square, and Warehouse District areas. Like never before, to city councilperson $\mathrm{R}$. Reeves (2011), "the downtown has been targeted for a massive change". At the same time, the rhetoric of a new Cleveland - one that suggests a city that has increased its cultural sophistication, consumptive opportunities for the middle class, and its economic attractiveness for business - has persisted (see Civic Task Force on International Cleveland, 2007).

Deft human agency has constantly been at work here. Agents and institutions on the ground have "run" with the new rhetoric and have toiled to push this go-global restructuring. Notably, city councilperson A. Said has fervently pushed for more usage of a city tax abatement program to attract residential and commercial developers at these sites. This post-1990 moribund program, Said has repeatedly noted to fellow political operatives, has to be recovered and reused used in each of these locations (Rosentroub et al., 2010). This program, designed to "remake Cleveland's core to the new realities of global times" (councilperson Said 2010), 
has been sold as a "city-building necessity" (councilperson Said 2010). Moreover, city councilperson A. Telop (2009) has been instrumental in pushing for relaxed zoning codes and zoning variances in these locations to "fuel the necessary infusion of capital that would reculturalize the core" (Cleveland planner A. Telop 2009). Strenuously and successfully lobbying for this change across the aisles of city hall, Telop has identified zoning changes as "a key ingredient to making what Cleveland needs ... this is how these programs should be operating".

Charismatic and savvy developers have also translated the rhetoric into a tangible socio-physical restructuring. Scott Wolstein, chair and CEO of Wolstein Group, has maneuvered through Cleveland's complex web of permitting and politics to build Flats East Bank (opened in 2013). Wolstein has pieced together a powerful set of political and economic supporters - Greater Cleveland Partnership, Cleveland International Fund of Cuyahoga County, Cleveland-Cuyahoga County Port - to offer a "global reaching" USD 522 million retail and office gargantuan along the lake (the largest publicprivate partnership in Cleveland's history). King Group, led by CEO Donald M. King, has adroitly negotiated Cleveland's turbulent real-estate market to build a multiplicity of commercial and residential projects that now dot Cleveland and Ohio. Speaking to Cleveland's need to "shine itself up" and be internationally competitive in current times, it currently owns and manages more than 2 million square feet of commercial space.

But there is a darker side to all of this: these projects have been designed and regulated to systematically exclude the poor, especially poor blacks. In architectural layout, physical design, police monitoring, and zoning specification, the message has been clear: a "problem minority" diverges from these spaces" texture and purpose and is to be repelled. A glut of community-retreating (inward-oriented) condos, rental units, office retail structures, and office properties easily and casually surveil the streets, and are landscaped to convey a kind of new class takeover. The layers of symbolism implanted have been undeniable: these spaces have been recolonized by a new breed of people; they are its supposed proper occupiers. All of this activity has been undergirded by a city plan - "Cleveland 2020" - that emphasizes redeveloping of the downtown and these spaces for "more livability". In translation and practice, city councilperson D. Wette (2009) admits, livability here has meant changing the downtown's character to enhance a middle-class aesthetic and social sensibility.

The outcomes of these new developments today are visible: easily monitoring and surveilling cul-de-sacs, intensified police patrol and regulation, and rental and homeownership prices that preclude residency by the non-middle class. Locals know who is welcome here and who is not. As one black youth put it to me, "I seldom come around here [Old City] ... it's lame, I know I'm not wanted ... hey, it's in the air, it's in the place ... the rich, the fine upstanding, they're here and let you know about it ... I'd rather be in my community ... we all know and feel this; I'm not the only one."

There is another side to this restructuring. In the shadows of this concentrated upgrading, Cleveland's resource starved African-American communities have been further choked. East Cleveland, predominantly black and low- and moderateincome, has been most afflicted by the concerted restructuring effort elsewhere. Glenville, one of the 10 poorest neighborhoods in the United States, experienced a more-than-35\% decline in block grant funds received from 1990 to 2012, with a substantial reduction in funding for affordable housing, day-care provision, and job creation initiatives (Telop, 2009). City activist M. Evans (2012) calls this withdrawal of resources "not surprising, a reflection of the problems in getting any funding to help the poor. The Glenville area has been most hurt; the poor now do not know where to turn - it's [these are] desperate times ... people are told to use self-help [and] be business-like and tough: this is the new rhetoric of a supposedly progressive Cleveland".

Since 1990, poverty has intensified in its three poorest black ghettos, Hough, Glenville, and Collinwood. Currently, more than $60 \%$ of these households unofficially live below the poverty level (Rentgen, 2011). These neighborhoods today have infant mortality rates above 15 per 1000 , a figure that rivals Uruguay's 17 per 1000 and Mexico's 20 per 1000 (see CIA World Fact Book, 2003). On 105th Street in Glenville, only 15 min from Cleveland's vibrant downtown, almost every storefront is boarded up. In Collinwood, beggars and the homeless multiply across its main thoroughfare, 152nd Street, in a desperate fight to survive. Decimated by the recent mortgage foreclosure fiasco, it is estimated that Hough now has more than $35 \%$ of its residential parcels tax-delinquent, compared to the city's less than one in eight (Evans, 2012).

To make matters worse in these neighborhoods, its people, land, and property (like the rest of the city) are more strenuously subjected to market rule. Now, the private market is the new mantra to understand community condition and appropriate response. As planner S. Swerve (2009) put it, "As places for profit these neighborhoods are barely on the map ... they need to be made more economically attractive and enticing for them to be turned around". Moreover, Cleveland planner B. Hennepin $(2004,2012)$ notes "the continued black ghetto quandary" and pleas for "all of Cleveland and the ghetto to find resuscitation via the market, which will impose a needed order". As reflected in these quotes, the new entrepreneurial template applied across the city casts the die for something predictable: the further abandonment of these spaces by both the public and private sectors.

\subsection{Indianapolis}

In Indianapolis, the trope of globalization is somewhat different: it occupies center stage in the face of especially curious circumstances, stable job and industry growth in the 
city. Unlike Cleveland, then, economic eclipse has not been the case. Thus, the city expanded its number of jobs and industries by 3.7 and $4.0 \%$ between 1980 and 2000 (Center for Economic Development, 2004). Between 2000 and 2010, these numbers increased by 2.1 and $2.7 \%$ (US Census Bureau, 2010). Indy's economy, moreover, has been dominated by light industry and service provision and is hardly global and footloose, which the notion "global economy" references. Yet aggressive rhetoric about the need to entrepreneurialize city form has persisted under mayors William Hudnut, Stephen Goldsmith, Bart Peterson, and Greg Ballard. The results have been unsurprising: government resources have been steered away from neighborhood development and job creation and towards "culturalizing" and "aesthetically renewing" the city, and fostering gentrification.

The redevelopment regimes of mayors Hudnut, Goldsmith, Peterson, and Ballard have dramatically chiseled the new post-1990 uneven development into Indy's fabric. Governances have accomplished this using, like the ones in Cleveland, what have been deceptive neoliberal projects. Bold oratory of a retrenched government has barely concealed a new forceful local state that, as strictly as before, regulates land, property, and social service provision. Like Cleveland, the goal has been to heat up urban real estate via a mix of physical impositions and spatial banishings. Thus, the local state's post-1990 arsenal has added, in particular, new policing methods (Project Saturation, the Zero Tolerance Team), new land-use control devices (e.g., Operation Downtown Cleanup, which has emphasized the removal of the homeless from downtown streets), Workfare and No Child Left Behind, and the intensified subsidizing of downtown redevelopment (see Grunwald, 1998). A conservative local state, staunchly Republican in a starkly conservative city, has keenly inserted itself into local lives and the city's evolving spatial configuration.

In this context, a majestic centerpiece - an upscaled downtown - has been unwaveringly pursued. The ideal is elaborate: to build a new downtown that can function as a haven for the affluent where they can work, play, and luxuriate in discrete, fortressed spaces. Like Cleveland, these projects have been lucrative to real-estate interests (e.g., the Simons, J. Scott Keller) and have not been meaningfully job-creating or economically propulsive (see Wilson, 1996). The construction of cultural gargantuans Circle Center Mall, Conseco Fieldhouse, and White River Park are its epicenter. Gentrification, fueled by the city's provision of tax abatements and historic designation status, has also intensified in downtown neighborhoods (anchored in two spaces, Lockerbie Square and Fletcher Place). By the end of his second term (1992-1999), Mayor Steven Goldsmith had presided in funneling more than USD 1.5 billion in new downtown spending (Barrows, 1990). Sports stadia, upscale housing, restaurant rows, and theater blocks have replaced acres of working-class neighborhoods and open space. "Indiana-no- place", in short order, has gained national notoriety to become the Republican-hyped model for ideal city redevelopment in the United States (cf. Goldsmith, 2003b).

Adroit people and institutions on the ground have been important here. As in Cleveland, charismatic and savvy developers have translated the rhetoric into a tangible sociophysical restructuring. Most recently (in 2012), a partnership of veteran city developers, working with the Environmental Protection Agency, Indianapolis Department of Public Works, and the Department of Housing and Urban Development lobbied successfully to have a 9-acre (3.6 ha) downtown area remade as "the Indianapolis Smart Growth District". This partnership's cultivation of social capital, bank financing, land assemblage, and city technical support enabled the restructuring. It created a "neighborhood ... reborn as a vibrant, livable, sustainable, connected, and welcome community that is a model for neighborhood rebirth" (Indianapolis Smart Growth District, 2012). Similarly, city power broker Eli Lilly carefully pieced together land and public support around its downtown corporate headquarters to develop 14-acre CityWay in 2012. This dramatic project - containing a USD 44 million, 209-room, 4-star hotel; 3 retail buildings; and a 24000 square foot $\left(2229.7 \mathrm{~m}^{2}\right)$ mixed office retail building - has a USD 155 million residential complex at its center. The media has tabbed this "a new urban neighborhood" made possible by "an immense investment in sweat, vision, energy, and institutional consolidation" (Indianapolis writer M. Jones, 2012).

But in the shadows of the replenishing downtown, poor black neighborhoods have suffered. At the core of this, funds to meet the poor's housing and social needs have been substantially cut and often superficially used. Most notably, block grant dollars for Indy's poorest area, the Eastside, has declined by more than $40 \%$ while city-wide decline was less than $20 \%$ between 2000 and 2010 (Sargent, 2012). The once 35 subsidized day-care facilities and 8 counseling/drug treatment centers in 1980 had dwindled to 8 and 4 by 2000 and to 5 and 3 by 2010, respectively (Sargent, 2012). Funds to "distressed neighborhoods" have gone mainly to two sources: community development corporations (CDCs) and the National Center for Neighborhood Enterprise (NCNE). The city's seven major CDCs have used funds to mainly paint homes, fix up houses, repair torn streets, and enroll residents in entrepreneurial programs (Maher, 2010). They, like other CDCs across the urban United States, had become remarkably corporate and deradicalized by the 1990s (see DeFillipis, 2004). CDCs, operating in ascendant neoliberal times where their existence is tenuous, often function pragmatically as corporate collaborating entities (see Porter, 1997).

The other source of funds in Indianapolis for distressed neighborhoods, NCNE, has been conservative mogul Robert Woodson's national outreach center. His city development model pushes to re-entrepreneurialize social climates and physical spaces by nurturing individual responsibility and 
business acumen, and supplanting "bad culture". Its increased use across the inner-city United States, initially in trials, appeared widely as central government policy across numerous cities in the United States in the 1990s (it was embraced and widely used by John Norquist in Milwaukee, Rudolph Giuliani in New York, and Stephen Goldsmith in Indianapolis). Its implementation in Indianapolis has emphasized one pillar of this: faith-based programs and church-led social expertise to revitalize neighborhoods. At its core, it has turned more than 15 churches into major providers for social counseling, job expertise, drug control, and micro-enterprise classes (see National Center for Neighborhood Enterprise 2003). Each operates in the context of proffering faith-based and "good" cultural values: Indy's poor black neighborhoods are to be further established as isolated and compliant labor pockets.

In this setting, more than $50 \%$ of Eastside residents are unofficially below the poverty level, with underemployment rampant (Sargent, 2012). The fall-out is commonly noted by community leaders and residents. To Rev. Calvin Bryst (2013), a long-term supporter of local black youth in the area, increased crime has followed from worsened living conditions; he notes that "sometimes I feel these kids just barely have a chance". To Bryst, decent employment has all but disappeared, government is remote and hostile, and too many turn to illicit activities like selling drugs to survive. "It's tough here [the Eastside]", said Bryst, "not much work or positive stuff ... and conditions are plain difficult; don't let anyone fool you". In this context, to local activist Sargent (2012), vague interventionist strategies by volunteers (church officials, block groups) are the principal - and a limited corrective for the community's pressing needs.

Even momentary escape by residents from the grinding poverty is difficult. Random walks outside this Eastside area can easily prove shameful and demeaning, and, at their worst, deadly. The Indianapolis Police Department, notorious for its harsh enforcement of these social spaces (see Jet, 1995), rigorously polices the downtown area for "Eastside interlopers". To writer Fred Goldstein (2001), the police routinely "harass African-American youth and treat them as if they were violent gang members; the cops have 'jump-out boys' who jump out of squad cars and swoop down on black youth." And from our observations, police officers, black or white, move through the Eastside, paraphrasing James Baldwin, "like occupying soldier[s] in a bitterly hostile country". That is why, following Baldwin, the police ride in cars or walk in twos or threes. Poverty and blackness here, to city councilperson Glen Howard (2008), translate into a perception of intransigent culture and values. Such "troublesome" people, supposedly antithetical to cultivating a vibrant consumer and producer center, must be regulated and controlled. Not surprisingly, Indianapolis has experienced two large riots since 1995 over police brutality.

These ghettos in Indianapolis ultimately fall prey to a maxim that propels the Indy redevelopment machine: the need for growth leaders to be brutally efficient and to partition the city into separate social spheres given new hyperglobal times. The result is to further an ascendant reality: the creation of not one city - Indianapolis - but a multiplicity of disconnected places. What has emerged in Indianapolis is an expansive urban terrain simultaneously stable and on the edge, islands of differentiated spaces bonded only by the sense of being in a place called "Indianapolis". Downtown celebrated spaces, the new consumptive playgrounds, are forged as places of hard-rock stability, but at the expense of purging other people and spaces around it to create a multitude of disconnected and unequal "cities".

Neighborhood associations and housing groups in Indianapolis and Cleveland have not totally wilted in the face of this reality: some have operated "below" CDCs but in a problematic state: with depleted funds. The head of a social service agency in Indianapolis put it as follows: "It's [helping the poor] just no longer popular and seen as important to city improvement. The city more than ever caters to the needs of builders and developers who want to gentrify; that's the priority" (Sargent, 2012).

\section{Conclusions}

This study builds on a recognition that a global trope now powers current redevelopment in many global north cities (focusing on two prototypical cities, Cleveland and Indianapolis) and suggests two important points. First, that this global trope is a remarkably complex, multitextured human construct. As a deft human accomplishment, this constituting and "delivery" relies upon an adroit staging of the world's and city's composition. The global trope, it is shown, speaks about a multiplicity of things - what people are, what the city is, what processes are, what society is, what the world is. This elaborate staging - Robin Wagner-Pacific's (1996) "discursive surround" - provides the offered global fear with a unity of meanings and values. One reality, in rich emotive and provocative detail, becomes advanced while alternatives are purged. Here is Mikhael Bakhtin's (1981) dialectic of asserted truths and implicit dialogue with other visions, the simultaneity of asserting one vision of city and world and annihilating others. In elaborate framing, the trope serves up a supposed frank and blunt package of truths about city realities and needs that can no longer be suppressed. In assertion, its pleas correspond to nothing less than core truths.

Second, this global trope profoundly exacerbates existing socio-spatial inequalities in these cities as a central rhetorical resource that advances one redevelopment vision. Redevelopment governances, as authors of this rhetorical trope, use it to offer an array of programs and policies that reinforce and deepen patterns of class-racial segregation. In the process, select spaces - i.e., downtowns, new cultural districts, new leisure and tourist zones, and gentrified enclaves - become privileged as zones of public-sector and private-sector 
upgrading. Here are the "new spaces of global response" that supposedly hold the key to salvaging the city economically and socially in turbulent global days. Alternatively, zones of marginalization, i.e., low-income black and Latino communities, become all-but obliterated from the public gaze. Once barely on the public's radar, they now have fallen even further off of it. To be sure, these governances have not invented this global concept and are not responsible for its existence. But in robust oratory, they now aggressively draw on it, reproduce it, and normalize it as a recognized "opportunity structure" to advance their political designs.

We should not be totally surprised that a politically inspired global-speak now assumes prominence in these cities. Tweaking an old adage, if globalization did not exist, humans would have to create it, for much political mileage can be gained from this as a decisive offering. But there is something startling about this recognition of its usage today: it is now globalization as an image and a fear, as much as a reality, that today activates people and institutions in these cities to take actions that drive a new uneven development. This inspired global-speak today profoundly reverberates through the fabric of these cities. At the moment, global-speak has assumed a dominant and privileged intellectual position. While the future of this construct is uncertain given its tendency to afflict many people, it seems to be motoring along as a deft, flexible human construct. Effectively problematizing this construct, it seems, will be a monumental human task.

Edited by: O. Söderström

Reviewed by: two anonymous referees

\section{List of Interview Partners}

Braggs, B. (2004, 2013): Planner. City of Indianapolis.

Bryst, C. (2013): Church head. Cleveland

Evans, M. (2012): Housing activist. Cleveland.

Hawes, S. (2009): Planner. City of Indianapolis.

Hennepin, B. (2004): Planner. City of Cleveland.

Henry, M. (2008): Representative. City of Indianapolis.

Howard, G. (2008): City-county councilor. City of Indianapolis.

Jenks, C. (2004): Planner. City of Cleveland.

Jones, M. (2012): Writer. Indianapolis Star.

Maher, T. (2010): Professor. University of Indianapolis.

Marks, G. (2008): Planner: City of Cleveland.

Moos, A. (2008): City councilperson. City of Cleveland.

Plann, S. (2004): Planner. City of Cleveland.

Porsky, E. (2012): Planner. City of Indianapolis.

Reeves, R. (2011): City councilor. City of Cleveland.

Rentgen, M. (2011): Planner. City of Cleveland.

Rhoads, M. (2011): Planner. City of Indianapolis.

Said, A. (2010): City councilperson. City of Cleveland.

Sargent, B. (2012): City activist. Indianapolis.
Skrabec, J. (2004): Worker. Department of Community Development, City of Cleveland.

Swerve, S. (2009): Planner. City of Cleveland.

Telop, A. (2009): City councilperson. City of Cleveland.

Wallach, M. (2004): Planner. City of Cleveland.

Wette, D. (2009): City councilperson. City of Cleveland.

\section{References}

Anderson, S. and Cavanaugh, J.: Top 200: the rise of global corporate power, in: Global Policy Forum, New York - Technical report, 77 UN Plaza, Suite 3D, 2000.

Bakhtin, M.: The Dialogic Imagination, University of Texas, Austin: University of Texas Press, 1981.

Cameron, A. and Palen, R.: The Imagined Economy: Mapping Transformation in the Contemporary State, in: State/Space: A Reader, edited by: Brenner, N., Jessop, B., Jones, M., and Macleod, G. (Hrsg.), Oxford, 165-184, 2003.

Center for Economic Development: After the boom: joblessness in Milwaukee, Milwaukee, Technical Document from Publisher 2004.

CIA World Fact Book: Technical report, federal government document, Washington DC, 2003.

City of Indianapolis: The consolidated plan. Technical report. Division of Community Development, Department of Metropolitan Development, 2003.

Civic Task Force on International Cleveland: Recommendations to the City of Cleveland, City of Cleveland, 2003.

Civic Task Force on International Cleveland: Cleveland as an international community, City of Cleveland, 2007.

Cox, K.: The local and the global in the new urban politics: a critical review, Environment and Planning D: Society and Space, 11, 433-448, 1993.

Dalke, A. and Grabstein, P.: Three dimensional storytelling, Journal of Teaching Writing, 23, 11-19, 2007.

DeFilippis, J.: Unmaking Goliath, London: Routledge, 2004.

DiMora, J.: Commissioners poised to boost arts, again! Media release, Cuyahoga County Department of Development, 2005.

Goldsmith, S.: Putting faith in neighborhoods: making cities work through grassroots citizenship, Indianapolis: Hudson Institute, $2003 \mathrm{a}$.

Goldsmith, S.: Introduction. The Entrepreneurial City: A How-To Handbook for Urban Innovators, New York, 1-10, 2003b.

Goldstein, F.: Police brutality - from L.A. to New York, it happens every day, Workers World, 22, 11-17, 2001.

Grunwald, M.: The myth of the supermayor, American Prospect, 40, 4-7, 1998.

Hackworth, J.: Faith based religious neoliberalism and the politics of welfare in the united states, Athens, University of Georgia, 2012.

Harvey, D.: The Postmodern Condition, Oxford, Blackwell, 1989.

Harvey, D.: Rebel Cities, Oxford, Blackwell, 2012.

Hudnut, W.: The Hudnut Years in Indianapolis, Bloomington, Indiana University Press, 1995.

Indianapolis Regional Center Plan: Comeback cities: the prospects for a continuing urban renaissance, Department of Metropolitan Development, City of Indianapolis - Technical report, available from IndyStar.Com (2001) Library fact files, Stephen Goldsmith, http://www.indystar.com, 2001. 
Indianapolis Smart Growth District: Christmas in Uptown-website www.smartgrowthindy.org, 2012.

Indystar.com: Library fact files, Stephen Goldsmith, website www. indystar.com, 2001

Jain, P.: Regeneration of Cuyahoga Flats [de] industrialized riverfront in Cleveland, Ohio, Unpublished thesis: University of Illinois, Dept. of Landscape Architecture, 2011.

Jet: Riots, unrest plague three cities after police shootings, allegations of brutality, p. 11., 1995.

Kennedy, L.: Race and Urban Space in American Culture, London, Edinburgh University Press, 2000.

Kirkpatrick, L. and Smith, M. P.: The infrastructural limits to growth: rethinking the urban growth machine in times of fiscal crisis, International Journal of Urban and Regional Research, 35, 477-503, 2011.

Lakoff, G. and Johnson, M.: Metaphors we live by. Chicago, University of Chicago, 1985.

Langellier, K.: Storytelling in Daily Life: Performing Narrative, Philadelphia, Temple University Press, 2004.

Machimara, T.: symbolic use of globalization in urban politics in Tokyo, International Journal of Urban and Regional Research, 22, 183-194, 1998.

Macleod, G.: Urban politics reconsidered: Growth machine to postdemocratic city, Urban Studies, 48, 2629-2660, 2011.

Macleod, G. and Jones, M.: Renewing urban politics, Urban Studies, 48, 2443-2472, 2011.

Margulis, H. L.: Predicting the growth and filtering of at-risk housing: Structure ageing, poverty and redlining, Urban Studies, 35, 1231-1259, 1998.

Miller, D.: Unspinning the globe, Red Pepper, 2003.

Mosimen, D.: Mayors get boost from corporations, Wisconsin State Journal, 1, 1-3, 2002.
Nash, K.: Contemporary Political Sociology: Globalization, Politics, and Power, New York, Wiley, 2010.

National Center for Neighborhood Enterprise: Empowering America's communities, Center, Washington, DC, 2003.

Porter, M.: New strategies for inner-city economic development, Economic Development Quarterly, 11, 11-27, 1997.

Rauch, E.: Is globalization exaggerated? Website http://groups. csail.mit.edu/mac/users/rauch/misc/globalization/, 2013.

Rosentraub, M. S, Mikelbank, B., and Post, C.: Residential property tax abatements and rebuilding in Cleveland, Ohio, State and Local Government Review, 42, 104-117, 2010.

Triozzi, R.: Website 'Triozzi For Mayor', http://www.blog01. kintera.com/Triozzi/, 2005.

US Census Bureau: data on housing characteristics at the census tract and census block levels, 2010.

Wagner-Pacific, R.: Discourse and Destruction, University of Chicago, Chicago: University of Chicago Press, 1994.

Warf, B. and Holly, B.: The rise and fall and rise of Cleveland, Annals of the American Academy of Political and Social Science, 511, 208-221, 1997.

Wilson, D.: Metaphors, growth coalitions, and black poverty neighborhoods in a US city, Antipode, 28, 72-97, 1996.

Wilson, D.: Toward a contingent neoliberalism, Urban Geography, 25, 771-783, 2004

Wilson, D.: Inventing Black-On-Black Violence: Discourse, Space, Representation, New York, Syracuse University Press, 2005.

Wilson, D.: Cities and Race: America's New Black Ghettos, London, Routledge, 2007.

Wimsett, W.: The fear economy, Adbusters Magazine, 21, 10-12, 1998. 